УДК 37

DOI $10.21661 / \mathrm{r}-471923$

\title{
A.A. Лanmeв
}

\section{ПРОФЕССИОНАЛЬНЫЕ ЦЕННОСТИ ОФИЦЕРА ВОЙСК НАЦИОНАЛЬНОЙ ГВАРДИИ РОССИЙСКОЙ ФЕДЕРАЦИИ}

Аннотация: в статье рассмотрен вопрос профессиональных иенностей офиџера наџиональной гвардии Российской Федераџии. По мнению автора для формирования устойчивости системы необходимо обретение комплексом знаний, основанных на неизменных духовных ценностях, определяющих всю стройность, гармоничность и жизнеспособность окружающего мира.

Ключевые слова: профессиональные ценности, офицер, национальная гвардия, Российская Федерация.

\section{A.A. Laptev}

\section{PROFESSIONAL VALUES OF THE OFFICER OF THE NATIONAL GUARD OF THE RUSSIAN FEDERATION}

Abstract: the question of professional values of the officer of the national guard of the Russian Federation is considered in the article. According to the author, to form the stability of the system it is necessary to acquire a set of knowledge based on unchanging spiritual values that determine the entire order, harmony and viability of the surrounding world.

Keywords: professional values, officer, national guard, the Russian Federation.

Руководство страны на данном этапе развития общества и государства, с учетом современном вызовов для выполнения задач возложенных на Росгвардию, опирается, прежде всего, на ее офицерский корпус как наиболее образованный и профессиональный блок данной структуры. Соответствующими выглядят и требования к профессионализму офицеров Росгвардии, их воинское мастерство, духовную основу которого составляют профессиональные ценности. 
Войскам национальной гвардии, необходим профессионал, обладающий не только профессиональными знаниями, умениями, навыками, профессиональной компетентностью, но и сформированной и развитой системой ценностных координат, определяющих офицера войск национальной гвардии Российской Федерации как основное управленческое звено - организатора служебно-боевой деятельности своего подразделения (группы, службы) или воинской части.

Одной из важнейших ценностей с одной стороны и проблемой для науки, занимающейся государством и государственным устройством с другой стороны, является моделирование, установление и поддержание осуществленного на практике конституционного (государственного) строя. При этом вектор этого установления будет зависеть от целей и задач, которые ставило перед собой государство при своем формировании, вокруг их решения оно и зарождалось, объединяя под свои знамена общественные массы людей. Если государство создается на короткий срок под конкретные задачи, например завоевание каких-либо территорий, оно функционирует вокруг формирования воина, но такая система (Древняя Спарта) будет находиться в устойчивом развитии только при проведении учений или участии в военных походах. Государство основной целью, которого стоит формирование человека-философа (Древняя Греция) в своем жизненном пути продвинется гораздо дальше, потому что в большинстве своем жители городов-полисов свое развитие видят в гармоничном существовании, себя как беззаботного дитя Природы. Единственной опасностью такого пути развития может стать столкновение интересов с государствами, пересыщенными воинскими подразделениями. Примеров падения процветающих государств под гнетом кочевников масса (Британия - англосаксы, Греция - римляне, Рим в свою очередь под натиском гуннов и т. д.).

Таким образом, на основании глубокого анализа исторического развития общества проявляется ценностная необходимость сбалансированного формирования человека способного в мирное время заниматься научно-производительным трудом, а в условиях внешней экспансии к мероприятиям по сдерживанию и дальнейшему выдворению неприятеля за пределы территории своего обитания. 
То есть общественная система, стремящаяся к устойчивости долгосрочного развития, на основе ценностных маяков, должна научиться сохранять много векторный баланс, в том числе в условиях внешних или привнесенных из вне внутренних неблагоприятных воздействий [4].

Н. Луман отмечает, что подобно любой другой системе, общество как система имеет свою окружающую среду, от которой система сама себя отличает и с которой она соотносится. Окружающей средой общества как системы являются материальные и духовные ценности [5, с. 31]. Это отчасти является необходимым условием стабильного развития самой системы, которая в отсутствии морально-нравственных «маяков», будет то и дело стремиться налететь на «рифы» всеобщего падения нравов, денежных целеполаганий и как следствие неизбежному саморазрушению.

Так по этому поводу К. Аксаков пишет: «Вся сила в идеале. Да и что значат условия и договоры, как скоро нет силы внутренней? Никакой договор не удержит людей, как скоро нет внутреннего на это желания. Вся сила в нравственном убеждении. Это сокровище есть в России, потому что она всегда в него верила и не прибегала к договорам» [1, с. 148].

В настоящее время стратегия развития российской науки отдает приоритет тем исследованиям, которые являются жизненно-значимыми для самой перспективы существования мирового сообщества, для его устойчивого и безопасного развития [3].

По нашему мнению, для формирования устойчивости системы необходимо обретение комплексом знаний, основанных на неизменных духовных ценностях, определяющих всю стройность, гармоничность и жизнеспособность окружающего мира. При этом целостность мировоззрения чаще всего определяется восприятием мира, миропониманием, отношением человека ко всему сущему. Наличие нравственно-ценностного стержня у каждого человека в обществе будет являться основой, опорой и, если хотите арматурой в фундаменте всей общественно-государственной системе. И чем больше этих армирующих элементов в государстве, тем более сильные воздействия как извне, так и изнутри оно 
способно удержать. И коль мы взялись использовать эзопов язык, в продолжение хотелось бы сказать, что офицерский корпус в России всегда являлся самой твердой и закаленной арматурой нашей государственности, благодаря которой мы со своим великим народом до сих пор не потеряли своей идентичности.

Одним из возможных путей развития общества и образования могли бы стать теоретические положения, высказанные еще Л. Гумилевым про руководителей-пассионариев, которые при оптимальном численном соотношении в дуальности - «субъект - объект», «начальник - подчиненный», могли бы эффективно управлять различными людскими объемами в зависимости от уровня полученных знаний и сформированных навыков. Один из учеников на утверждение учителя про то, что все ученики - это «алмазы», а каждый учитель, качественно граня свою сторону, делает камень драгоценным, и чем больше граней и степень обработки, тем камень дороже, когда-то спросил: «Что алмаз до состояния бриллианта можно обработать только при наличии алмазного инструмента?». Исходя из ответа на этот вопрос можно с уверенностью сказать, что преподаватель высшей школы в том числе и высшей военной школы перед началом «обработки», должен иметь четкое представление, основанное на оформленных данных вступительных квалификаций, какой исходный «материал» будь то «глина», «дерево», «камень», «алмаз» перед ним. И только тогда, когда сформировано четкие представления можно брать в руки инструменты, то есть выбирать методологию и технологию обучения, в противном счете мы можем начать пильть «глину» алмазным кругом, в результате и материал загубим и инструмент испортим, а цели не достигнем [2].

Таким образом, интегральным показателем эффективности воспитательного процесса военного вуза Т.В. Сидорина считает уровень сформированности у курсантов социальной зрелости [6], который становится результатом правильно выбранной методологии обучения и воспитания помноженного на эффективную управленческую и, если даже хотите маркетинговую политику вуза. Для того чтобы развивать систему высшего в том числе и военного образования страны, мы четко должны представлять из какого материала и какого уровня 
обработки мы будем строить здание нашей государственности. В сказке про трех поросят здания были из разного материала и исход для их обитателей был тоже различен. А быть может люди, занимающиеся вопросами формирования и укрепления государственного суверенитета, будут основываться на сбалансированном использовании лучших качеств каждого из перечисленных выше человеческих типов.

\section{Список литературь}

1. Казакова Л.И. Человек в системе духовной жизни общества. - М.: Инфра, 2000. -175 c.

2. Лаптев А.А. Развитие науки и образования как факторы укрепления государственного суверенитета [Текст] // Развитие военного образования в контексте обеспечения военной безопасности Казахстана: Сбор. матер. междунар. науч.-практич. конф.- Петропавловск: ВИ НГ Республики Казахстан, 2018. - Ч. 2. - C. 92-94.

3. Лаптев А.А. Управление процессом повышения ценности образовательной услуги // Международный научно-исследовательский журнал. - 2015. - №1 (32). - Ч. 2. - Екатеринбург, 2015. - С. 53-56.

4. Лаптев А.А. Этические проблемы развития современной науки [Текст] / А.А. Лаптев, С.В. Полунин // «Новое слово в науке: перспективы развития»: сб. матер. XI междунар. науч.-практ. конференции / под ред. О.Н. Широкова. - Чебоксары: Чувашский гос. ун-т им. И.Н. Ульянова, 2017. - №1 (11) - С. 247-249.

5. Лубский Р.А. Политический менталитет: Методологические проблемы изучения и российские реалии: Дис. ... канд. филос. наук / Р.А. Лубский. - Ростов н/Д, 1999. -208 с.

6. Сидорина Т.В. Подготовка курсантов Росгвардии к профессионально-воспитательной деятельности / Т.В. Сидорина, А.А. Зотов, Д.Ю. Тарасов // Современные исследования социальных проблем. - 2017. - №2-2. - С. 205- 208. - doi:10.12731/22187405- 2017-2-2-205-208. 


\section{References}

1. Kazakova, L.I. (2000). Chelovek v sisteme dukhovnoi zhizni obshchestva., 175. M.: Infra.

2. Laptev, A.A. (2018). Razvitie nauki i obrazovaniia kak faktory ukrepleniia gosudarstvennogo suvereniteta. Razvitie voennogo obrazovaniia $\mathrm{V}$ kontekste obespecheniia voennoi bezopasnosti Kazakhstana, 92-94. Petropavlovsk: VI NG Respubliki Kazakhstan.

3. Laptev, A.A. (2015). Upravlenie protsessom povysheniia tsennosti obrazovatel'noi uslugi. Mezhdunarodnyi nauchno-issledovatel'skii zhurnal, 1 (32), 53-56. Ekaterinburg.

4. Laptev, A.A., \& Polunin, S.V. (2017). Eticheskie problemy razvitiia sovremennoi nauki. "Novoe slovo v nauke: perspektivy razvitiia" 1(11), 247-249. Cheboksary: Chuvashskii gos. un-t im. I.N. Ul'ianova.

5. Lubskii, R.A. (1999). Politicheskii mentalitet: Metodologicheskie problemy izucheniia i rossiiskie realii: Dis., 208. Rostov n/D.

6. Sidorina, T.V., Zotov, A.A., \& Tarasov, D.Iu. (2017). Podgotovka kursantov Rosgvardii k professional'no-vospitatel'noi deiatel'nosti. Sovremennye issledovaniia sotsial'nykh problem, 2, 205-208. doi:10.12731/2218-7405-

Лаптев Алексей Анатольевич - аспирант, старший преподаватель, начальник кафедры, подполковник юстиции ФГКВОУ ВО «Новосибирский военный институт им. генерала армии И.К. Яковлева войск национальной гвардии Российской Федерации», Россия, Новосибирск.

Laptev Aleksey Anatolievich - postgraduate, senior lecturer, head of department, lieutenant colonel of justice at the Novosibirsk Military Institute named after I.K. Yakovlev of national guard of the Russian Federation, Russia, Novosibirsk. 